\section{CHROMOSOMES OF HUMAN CANCER CELLS}

BY

\section{A. I. SPRIGGS, D.M., M.R.C.P.}

M. M. BODDINGTON, M.A., B.Sc.

Cytodiagnostic Unit, Department of Pathology. United Oxford Hospitals

AND

C. M. CLARKE, Ph.D.

M.R.C. Radiobiological Research Unit, Harwell

Obvious mitotic abnormalities have long been known to occur very commonly in malignant tumours, but as a result of recent improvements in technique much more reliable cytogenetic observations are now possible. Transplantable tumours were the first to be accurately examined, and these were found to consist of populations of cells with variations around a modal ("stemline ") type which differs in each tumour (Makino and Kanô, 1953; Hauschka, 1953). Before 1956 cytological technique did not permit very exact analysis of human material, and until that date the normal human chromosome number of 46 was not known; however, several investigators performed counts and analyses of human malignant cells (Koller, 1947, 1956; Timonen, 1950 ; Hsu, 1954 ; Fritz-Niggli, 1955, 1956 ; Manna, 1955; Hansen-Melander, Kullander, and Melander, 1956 ; Levan, 1956 ; Ising and Levan, 1957). Since the introduction of hypotonic pretreatment it has been confirmed that abnormal stemline karyotypes are regutarly present in naturally occurring malignant tumours, both of animals (Ford, Hamerton, and Mole, 1958) and of man (Wakabayashi and Ishihara, 1958; Tabata, 1959 ; Makino, Ishihara, and Tonomura, 1959 ; Ishihara, 1959; Tonomura, 1959a, 1959b, 1960 ; Ishihara, Moore, and Sandberg, 1961).

During the past two years we have been collecting material from cases of human malignant disease, and making preparations to demonstrate the chromosomes. In this paper only the main results are summarized to give a general view of our experience.

\section{Materials and Methods}

The type of material studied has had to depend on technical limitations. Malignant effusions were selected for study if they contained numerous identifiable malignant cells, especially if there was a high mitotic rate, and these have been relatively easy to handle. Teased-out lymph nodes and brain tissue have also sometimes been successful. Solid tumours have only rarely given good results. Benign tumours have been inaccessible owing to their firmly held cells and their low mitotic rates. All materials have been prepared by a hypotonic citrate + Feulgen squash technique based on that of Ford and Hamerton (1956). There have been minor variations over the period of this study, but we describe the method now considered most satisfactory. Orcein spreads have also been tried; we have had occasional very good results, but it is difficult to obtain these consistently.

\section{Pleural, Peritoneal, and Other Fluids}

The fluid is collected with at least $1 / 10$ volume of $3.8 \%$ sodium citrate. As soon as possible, and always within a few hours, a sample (usually $10 \mathrm{ml}$.) is centrifuged to deposit the cells, and they are resuspended in $5 \mathrm{ml}$. of $0.9 \%$ sodium citrate. After half an hour at room temperature, $0.5 \mathrm{ml}$. of $45 \%$ acetic acid is added and mixed. After a further five minutes an equal volume of $60 \%$ ethyl alcohol is added and mixed. The tube is then centrifuged and the deposit resuspended in $30 \%$ ethyl alcohol. It can then be stored overnight.

Feulgen staining is performed on the cells in suspension. The cells are deposited by centrifuging and then resuspended successively in the following: $N \mathrm{HCl}$ at $60^{\circ}$ C. for eight minutes; distilled water; Schiff's reagent -1 hour ; distilled water ; $45 \%$ acetic acid.

The squashes are then made as follows. A drop of cell suspension (in $45 \%$ acetic acid) is placed on a clean grease-free slide. It is covered with a vinyl coverslip (these are made from "transovil" self-adhesive tape backed on the sticky side with very thin paper, and cut into squares). Pressure is applied to the coverslip with the thumb, through a piece of filter paper. On releasing pressure there is no tendency for bubbles to form

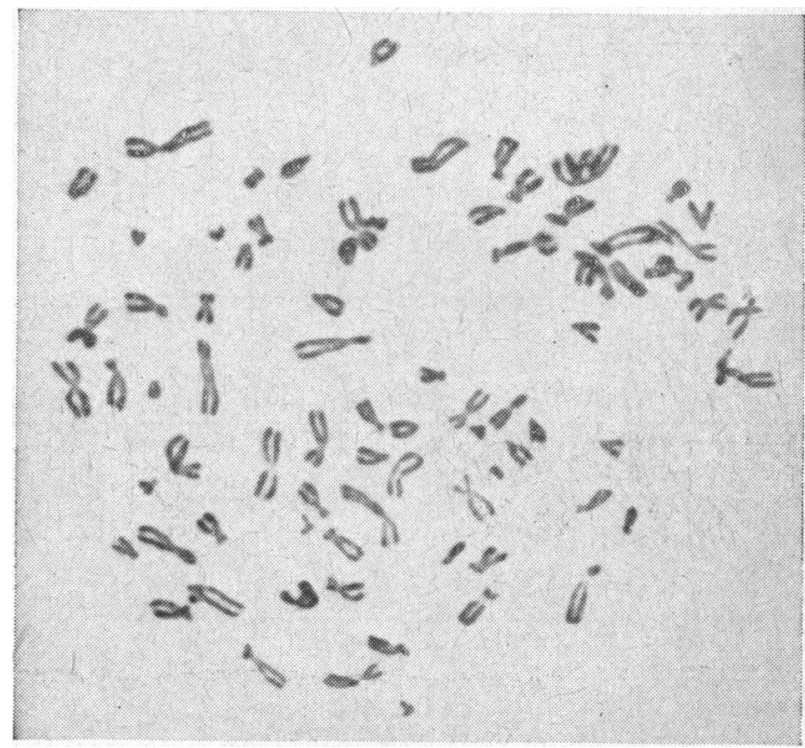

Fic. 1.-Case 3. Primary tumour (glioma) of temporal lobe. Cell showing 81 chromosomes. Feulgen squash.

beneath the coverslip, as may occur with glass covers. The slide is then placed against a block of solid $\mathrm{CO}_{2}$. When frozen, the plastic coverslip is pulled off; an overlapping edge makes this simple to perform. The slide is allowed to dry in air, and is then mounted in "euparal" under a glass coverslip. The preparations are permanent.

\section{Solid Tissues}

These are teased or scraped in $0.9 \%$ sodium citrate and left for balf an hour before proceeding as described above for the cells of effusions.

\section{NOTES TO HISTOGRAMS}

Black columns indicate that the karyotype was clearly abnormal. Cases marked with a were untreated at the time of the examination.

Case 14: Every cell had numerous chromatin fragments not included in the counts.

Case 21: Tumour cells were identified in the circulating blood. Three-day blood culture revealed one cell with 76 chromosomes, the rest being normal. 


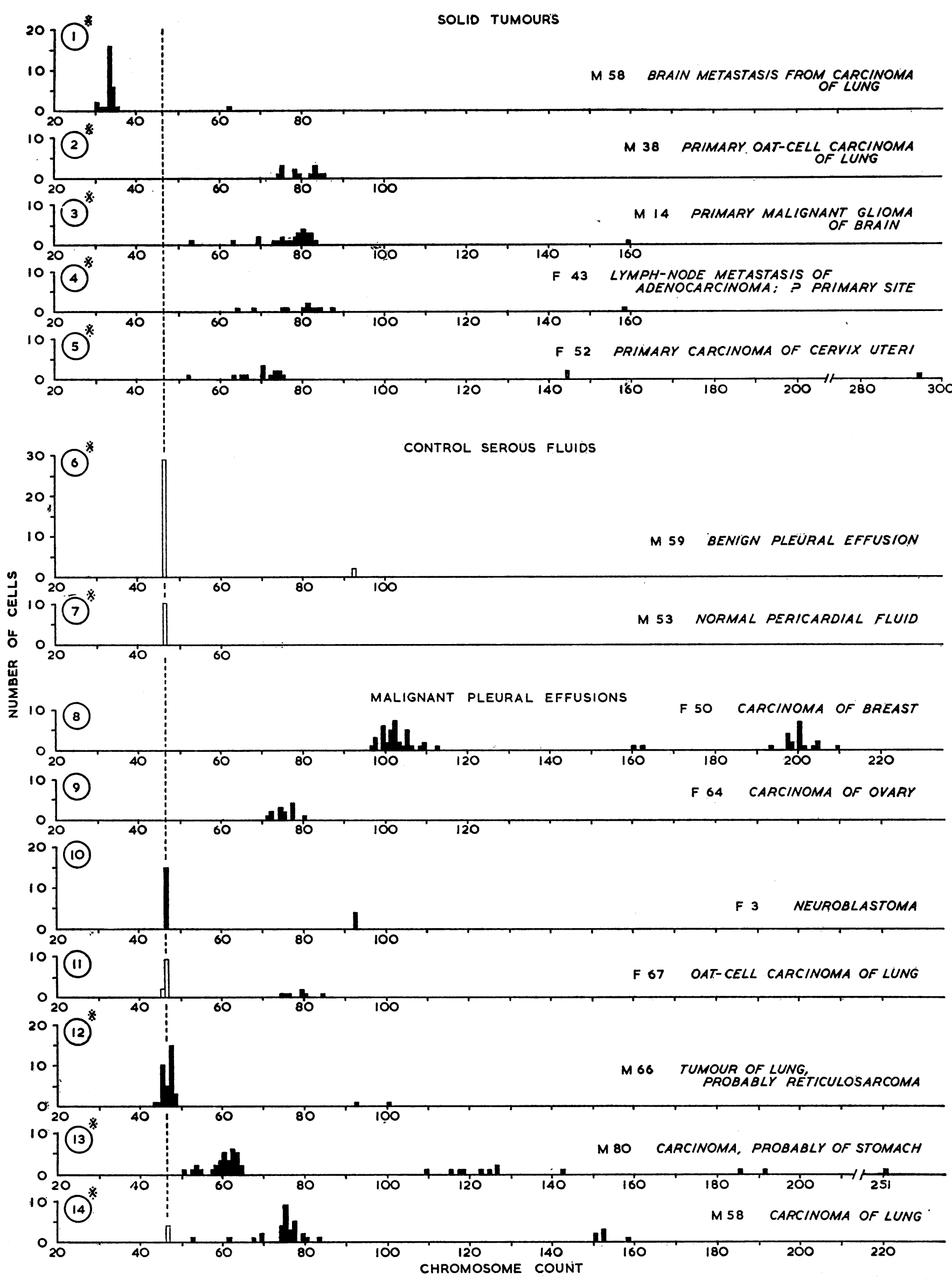




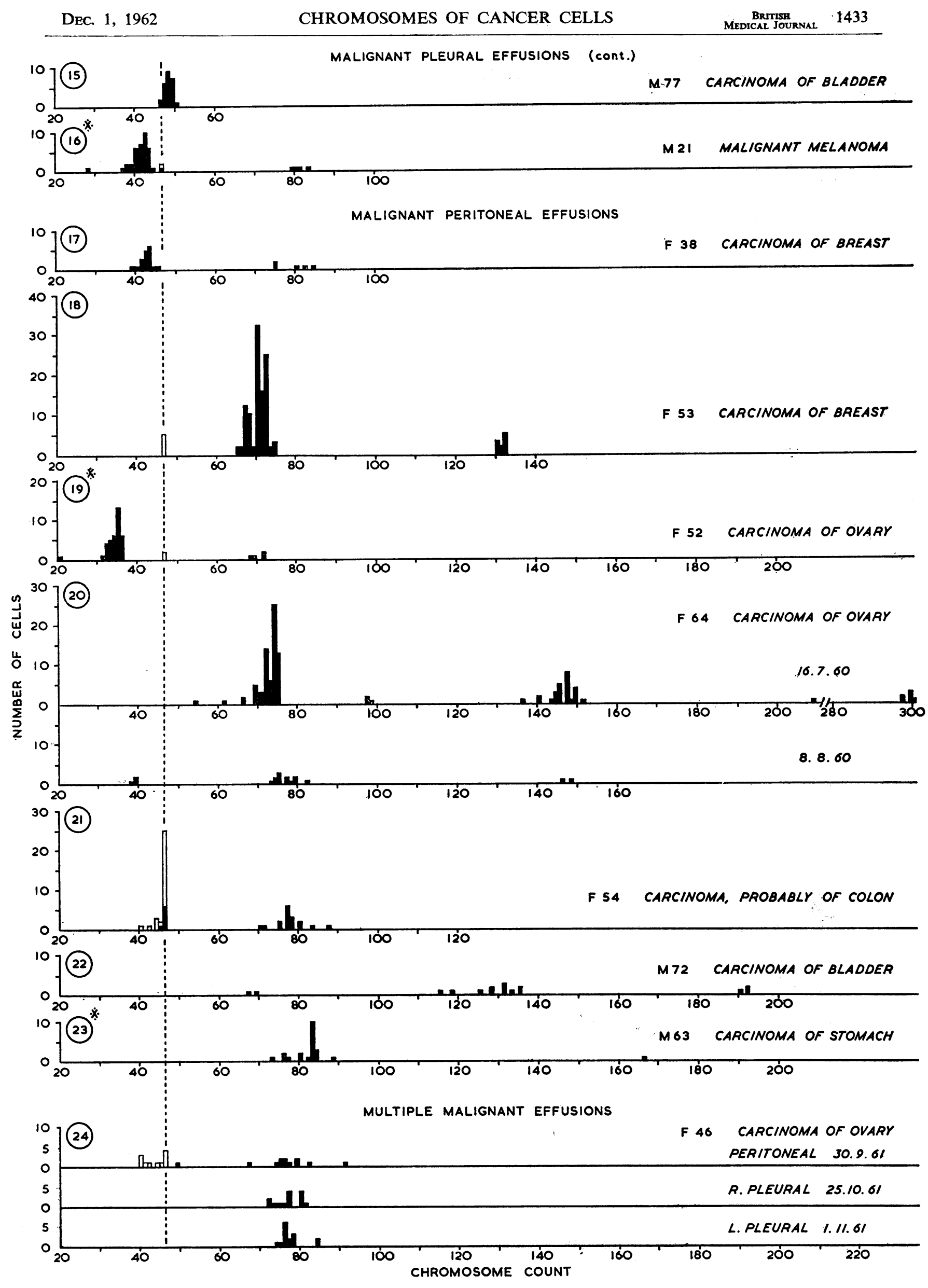


In some cases we have incubated the cells in 199 medium containing colchicine for varying periods before the hypotonic step: In others we have incubated effusions with an equal volume of 199 medium for 18 hours, then added colchicine (1 part per million) and incubated for a further two hours. These procedures have met with erratic success, but direct preparation is preferred.

\section{Results and Discussion}

The numerical findings in 24 cases are summarized in the accompanying histograms. Each shows the range of chromosome counts found in cells showing sufficiently well-spread metaphases. Cases in which overlapping chromosomes made counting difficult have not been included and we are satisfied that very little of the variation shown is due to observer error. A non-

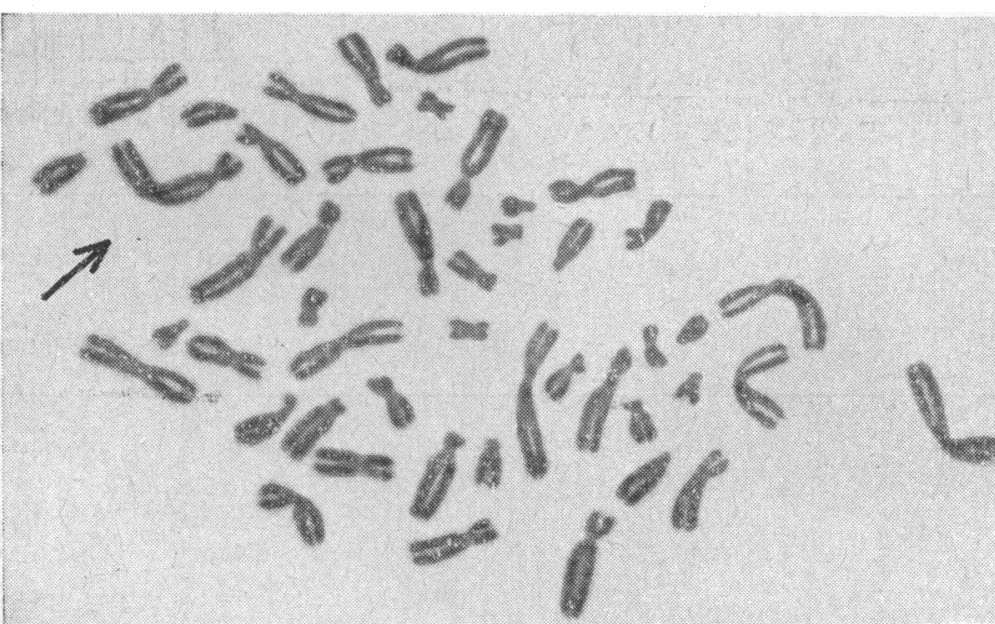

Fio. 2.-Case 15. Pleural effusion due to metastatic carcinoma of the bladder Abundant free tumour cells found in the fluid. The arrow indicates an abnorma long chromosome which was found in all the dividing tumour cells examined. Orcein spread. malignant pleural and pericardial fluid are included as controls.

In several of the histograms populations of normal (non-malignant) cells are shown. The types of cell dividing were always recognizable in stained films; for instance in Case 11 there were frequent mesothelial cells as well as tumour cells, and both types could be found in mitosis.

Some characteristic examples of dividing malignant cells are shown in Figs. 1, 2, and 3.

The findings in the present series permit the following generalizations to be made about the chromosomes of dividing human cancer cells. Abnormalities of chromosome number and/or of chromosome morphology are present, with a different pattern in each case. The chromosome number is not constant in any one case, but almost always shows at least some true variation about an abnormal modal value or values. Secondary peaks are often present at multiples of the modal number. Evidence of chromosome breakage and reunion is provided by the observation of dicentric chromosomes, rings, and other types of abnormality in some of the cases; and similar abnormal chromosomes in different cells of the same case strongly support the idea of origin from a single original malignant cell.

We have found no consistent relationship between the karyotypes of different tumours of the same histological kind.

It seems unnecessary to postulate any subtle invisible lesion to explain the malignant behaviour of carcinoma cells. With such serious derangements of their controlling chromosomes it is almost inconceivable that these cells should either function normally or be capable

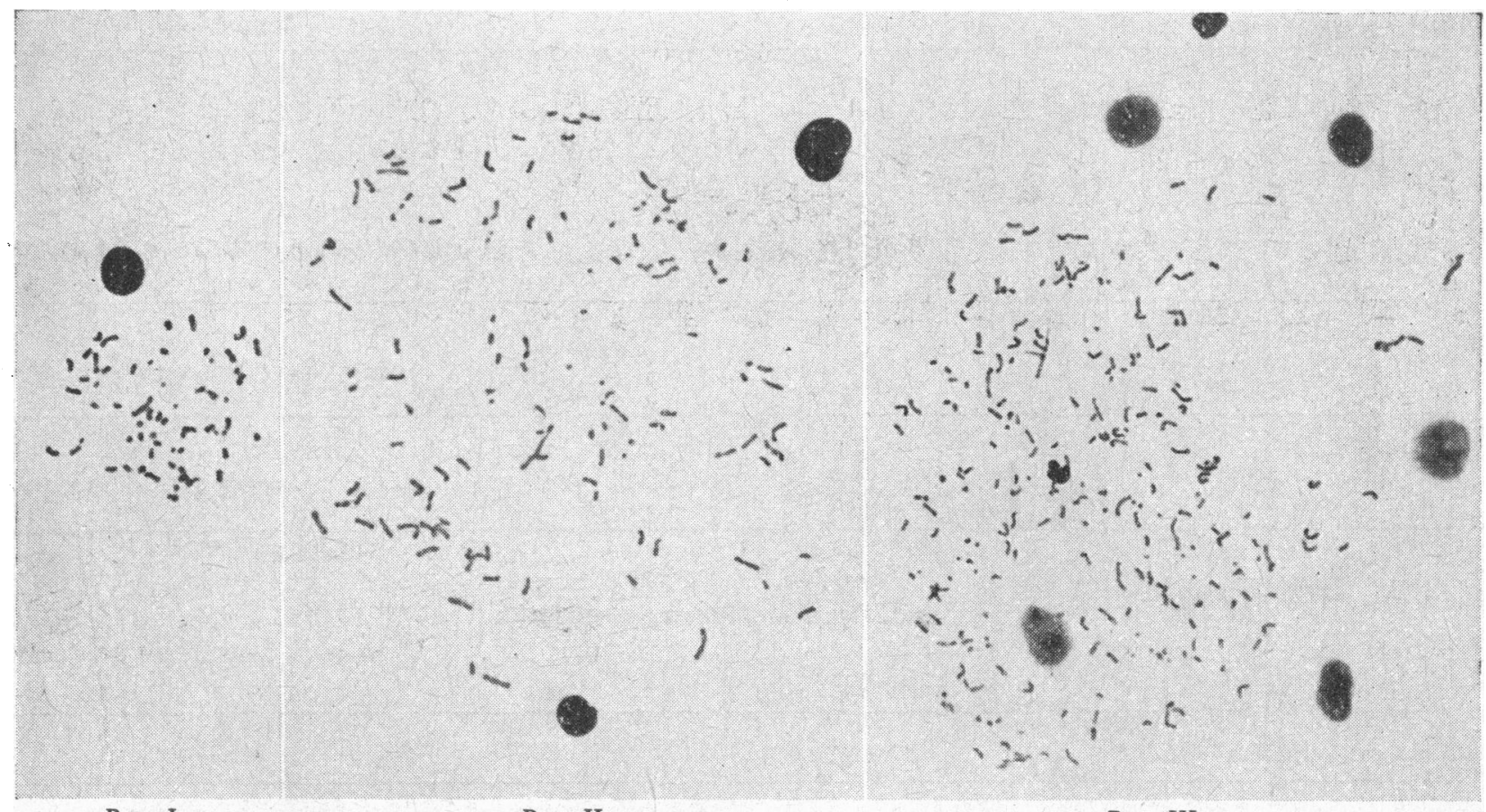

PaRT I

PART II

PART III

Fig. 3.- Case 13. Pleural effusion due to metastatic carcinoma, almost certainly of the stomach. Abundant malignant cells identified in the fluid. Three dividing malignant cells are shown, with chromosome counts of 61,124 , and 251 respectively. Feulgen squash. 
of turning back to form orderly tissues. It has sometimes been thought that chromosome changes may be a late or secondary manifestation of neoplasia. The evidence from carcinoma-in-situ of the cervix uteri (Spriggs, Boddington, and Clarke, 1962) suggests, on the contrary, that the karyotype may be altered before the development of invasive cancer.

Our results therefore provide support for the view that in the common types of malignant tumour each growth consists of a population of cells with an altered genotype, derived from a common parent. Their biological success is due, presumably, to the natural selection of successful variants. The random element in this process accounts for the uniqueness of each malignant tumour and explains the failure to find any biochemical abnormality specific for malignant cells.

\section{Summary}

The chromosomes have been examined in dividing cells from human tumours. Most of the successful preparations were from malignant effusions, and counts are given from 17 of these as well as from two control serous fluids. Counts from five solid tumours are also presented-three primary and two secondary.

Malignant cells were found to have abnormal karyotypes, with a different pattern in each case. There is some variation of the chromosome number around an abnormal modal value, which is usually more than 46 but occasionally less. Secondary peaks are often found at multiples of the modal number.

When cells with a normal karyotype are present as well they are explained by the occurrence of dividing normal cells in the same specimen (as shown in stained smears).

In many of the tumour-cell populations it is possible to recognize distinctive abnormal chromosomes in all the cells, although their chromosome counts vary. This presumably indicates descent from the same original malignant cell.

We should like to thank Dr. C. E. Ford for his advice during the preparation of this paper. Our thanks are also due to all those who have supplied us with specimens, and to the British Empire Cancer Campaign, who supported this work with grants to A.I.S. and M.M.B.

\section{REFERENCES}

Ford, C. E., and Hamerton, J. L. (1956). Stain Technol., 31, 247 and Mole, R. H. (1958). J. cell. comp. Physiol., 52. Suppl. 1, p. 235.

Fritz-Niggli, H. (1955). Oncologia (Basel), 8, 121.

Fritz-Niggli, H. (1955). Oncologia (Basel), 8,

Hansen-Melander, E., Kullander, S., and Melander, Y. (1956). J. nat. Cancer Inst., 16, 1067.

Hauschka, T. S. (1953). Trans. N.Y. Acad. Sci., Ser. II, 16, 64.

Hsu, T. C. (1954). J. nat. Cancer Inst., 14, 905.

Ishihara, T. (1959). Gann, 50, 403.

- Moore, G. E., and Sandberg, A. A. (1961). J. nat. Cancer Inst., 27, 893 .

Ising, U., and Levan, A. (1957). Acta path. microbiol. scand., 40, 13.

Koller, P. C. (1947). Brit. J. Cancer, 1, 38.

(1956). Ann. N.Y. Acad. Sci., 63, 793.

Levan, A. (1956). Cancer, 9, 648.

Makino, S., Ishihara, T., and Tonomura, A. (1959). Z. Krebsforsch., 63, 184.

and Kanô, K (1953), J. nat. Cancer Inst., 13, 1213

Manna, G. K. (1955). Naturwissenschaften, 42, 253. Spriggs, A. I., Boddington, M. M., and Clarke, C. M. (1962).

Tabata, T. (1959). Cytologia (Tokyo), 24, 367.

Timonen, S. (1950). Mitosis in Normal Endometrium and Genital Cancer. Helsinki.

Tonomura, A. (1959a). Jap. J. Genet., 34, 401

(1959b). J. Fac. Sci., Hokkaido Univ. Series VI, Zool., 14, No. 2, 149. (1960). Gann, 51, 47.

Wakabayashi, M., and Ishihara, T. (1958). Cytologia (Tokyo), 23, 341 .
BIOCHEMICAL INVESTIGATION OF OUTBREAK OF INFECTIOUS HEPATITIS IN A CLOSED COMMUNITY

\author{
BY \\ D. M. GOLDBERG, M.B., Ch.B., B.Sc. \\ Registrar in Biochemisty
}

D. RIDDELL CAMPBELL, M.B., Ch.B., F.R.F.P.S.
Consultant Physician

From the Department of Biochemistry, Western Infirmary, Glasgow, Scotland

That elevations of serum glutamic oxaloacetic transaminase (S.G.O.T.) and serum glutamic pyruvic transaminase (S.G.P.T.) occur in infectious hepatitis was first shown by Wroblewski and La Due (1955, 1956b). Numerous reports, summarized in the valuable reviews by Wroblewski (1958) and Agress (1959), have since established the assay of these enzymes as a principal diagnostic measure in this disease.

It is clear that, during the course of an epidemic, anicteric forms of infectious hepatitis may exist - widely among the population at risk (Denber and Leibowitz, 1952 ; Capps and Stokes, 1952). The problem of investigating such anicteric cases of infectious hepatitis has been facilitated by the introduction of serum enzyme tests, and Wroblewski and La Due (1956a) have made a notable contribution by their study of a naturally endemic form of the disease in a closed community at Letchworth Village, New York. Their results led them to classify those with only transiently abnormal S.G.O.T. as carriers; those with only abnormal S.G.O.T. and abnormal thymol turbidity as subclinical cases; and those with symptoms, abnormal S.G.O.T., and abnormal thymol turbidity in the absence of overt jaundice as subicteric cases.

These studies have been extended by Bodansky and his associates at the Willowbrook State School, New York (Ward, Krugman, Giles, Jacobs, and Bodansky, 1958 ; Bodansky, Krugman, Ward, Schwartz, Giles, and Jacobs, 1959 ; Krugman, Ward, Giles, Bodansky, and Jacobs, 1959). Their work on the naturally occurring and artificially induced forms of the disease represents impressive evidence for the superiority of serum transaminase estimations over every other laboratory parameter in the detection of latent and subclinical cases, while their transmission experiments have confirmed the long period of infectivity which may precede the onset of icterus-up to three weeks-as well as the potential infectivity of otherwise healthy and symptomless carriers described by earlier workers (Paul, Havens, Sabin, and Philip, 1945 ; Havens, 1946a, 1946b ; Francis, Frisch, and Quilligan, 1946).

More recently, serum enzyme studies, including assay of S.G.O.T. and S.G.P.T., were applied to an outbreak of infectious hepatitis in Poppenlauer, West Germany (Schön and Wüst, 1961), in which the disease took an anicteric form in $70 \%$ of the cases. The authors concluded that the measurement of S.G.P.T. was the most sensitive test available for diagnostic and epidemiological purposes.

The opportunity arose for a study of subclinical cases of infectious hepatitis in a ship from India berthed in Glasgow, with a total crew of 236 . This study was undertaken as a result of two members of the catering 